\title{
A larger agglutinated foraminifer originally described as a marine plant: the case of Arthrodendron Ulrich, 1904 (Foraminifera), its synonyms and homonyms
}

\author{
MICHAEL A. KAMINSKI ${ }^{1}$, ALFRED UCHMAN ${ }^{2}$, THEODOR NEAGU ${ }^{3}$ \& CLAUDIA G. CETEAN ${ }^{4}$ \\ ${ }^{1}$ Department of Earth Sciences, University College London, Gower Street, London WCIE 6BT, UK and KLFR, 3 Boyne Avenue, Hendon, \\ London NW4 2JL, UK (e-mail: m.kaminski@ucl.ac.uk) \\ ${ }^{2}$ Institute of Geological Sciences, Jagiellonian University, ul. Oleandry 2a, 30-063 Kraków, Poland (e-mail: alfred.uchman@ing.uj.edu.pl) \\ ${ }^{3}$ Department of Paleontology, University of Bucharest, b-dul N. Balcescu 1, 70111 Bucharest, Romania (e-mail: theodor.neagu@yahoo.com) \\ ${ }^{4}$ Department of Geology, Babes-Bolyai University, str. Kogalniceanu 1, 400084 Cluj-Napoca, Romania (e-mail: ceteanc@yahoo.com)
}

\begin{abstract}
The large, agglutinated foraminiferal genus Aschemocella Vialov, 1966 (type species Aschemonella carpathica Neagu, 1964) and the body fossil Halysium Świdziński, 1934 (type species Halysium problematicum Świdziński, 1934) are herein synonymized with the genus Arthrodendron Ulrich, 1904 (type species A. diffusum Ulrich, 1904), a form originally described as a marine alga from Upper Cretaceous (Maastrichtian) flysch sediments of the Kodiak Formation of the Yakutat Group (formerly Yakutat Formation) on Pogibshi Island, Alaska. The species Aschemonella carpathica Neagu is regarded as a subjective junior synonym of Arthrodendron diffusum Ulrich, which is herein lectotypified and transferred to the Foraminifera. J. Micropalaeontol. 27(2): 103-110, November 2008.
\end{abstract}

KEYWORDS: Foraminifera, algae, systematics, Arthrodendron, Upper Cretaceous

\section{INTRODUCTION}

During the 1899 Harriman Geological Expedition to the coast of Alaska, a curious segmented body fossil was distinguished as a new genus and species Arthrodendron diffusum (Ulrich, 1904). It was described from flysch sediments of the Kodiak Formation (formerly Yakutat Formation, now Yakutat Group), near the town of Kodiak and was originally regarded as a fossil alga of unknown affinity (Ulrich, 1904). Similar fossils have been found in the Alpine and Carpathian Cretaceous and Palaeogene flysch deposits, where they have been given different names. Since the 1960s, they have been considered to be large agglutinated foraminifera (Geroch, 1960; Neagu, 1964), commonly under the genus Aschemonella Brady, 1879 or Aschemocella Vialov, 1966. The genus Arthrodendron Ulrich, 1904 is now regarded as an agglutinated foraminifera and the senior objective synonym for these foraminifera described from Alpine-Carpathian flysch deposits.

Such fossils have been reported often in the palaeontological literature as algae. As late as 1990, specimens of Arthrodendron, tentatively identified as 'fossil sea green alga', were described from the Upper Cretaceous Lupkov Beds in eastern Slovakia (Plička \& Thomka, 1990, pl. 49, figs 1-2).

The purpose of this paper is to clarify the generic affiliation of these large deep-sea agglutinated foraminifera based on restudy of the type specimens.

\section{BACKGROUND}

\section{The genus Arthrodendron}

The genus name Arthrodendron has had a troubled history and has been applied variously to a Carboniferous plant, marine algae and trace fossils. The first use of Arthrodendron was by Scott (in Seward, 1898) with reference to a specimen of calamitean plant stem from a North American coal field. Seward (1898) recognized three structural types of calamite stems that were regarded as subgenera belonging to the genus Calamopitus Williamson, 1871 - Calamodendron, Arthropytus and
Arthrodendron. In his textbook Studies in Fossil Botany, Scott (1900) elevated Arthrodendron to generic rank. Henceforth, the name 'Arthrodendron' became entrenched in the botanical literature as a type of a Carboniferous plant, and the name can still be found in the Encyclopaedia Britannica used in this sense. Unfortunately, neither Seward (1898) nor Scott (1900) designated a type species for 'Arthrodendron' and, therefore, the name in its original sense must be regarded as nomen nudum.

One year after Seward applied this name to a fossil plant, an enigmatic fossil was discovered by G. K. Gilbert during the 1899 Harriman Geological Expedition to Alaska and described by Ulrich (1904) in the expedition reports, which were reprinted by the Smithsonian Institution in 1910 (hence the publication date is sometimes erroneously cited as 1910). Found in sedimentary rocks of 'older than Cenozoic' age on Pogibshi Island opposite the town of Kodiak Alaska (referred to as 'Kadiak' in the expedition reports), the fossil was originally regarded as a fossil alga of uncertain affinity. Apparently unaware of Steward's description of Carboniferous calamite stems, Ulrich (1904) described and illustrated the fossil as 'Arthrodendron diffusum $\mathrm{n}$. gen. n. sp.' (Fig. 1). The species was described as follows:

"Branches moniliform, springing from a central point and spreading outwardly and upwardly so as the form a loose bush-like mass as much as $15 \mathrm{~cm}$ in diameter; divisions dichotomous, at intervals varying from $6 \mathrm{~mm}$ to over $20 \mathrm{~mm}$. Joints subelliptical, the lower half usually a little narrower than the upper half, $4 \mathrm{~mm}$ to $6 \mathrm{~mm}$ in length and from $2.2 \mathrm{~mm}$ to $2.28 \mathrm{~mm}$ in width; surface usually glossy and smooth, but where preservation is more favourable is covered by minute granules and punctae."

Based on this specimen (Ulrich, 1904; pl. 14, fig. 1; reproduced herein in Fig. 1), the genus Arthrodendron was thus defined: 'Plant ramose, bushy, the branches constricted at irregular intervals, and probably consisting each of a series of rounded or ovate, flattened (probably inflated) joints; surface of joints minutely granopunctate'. 


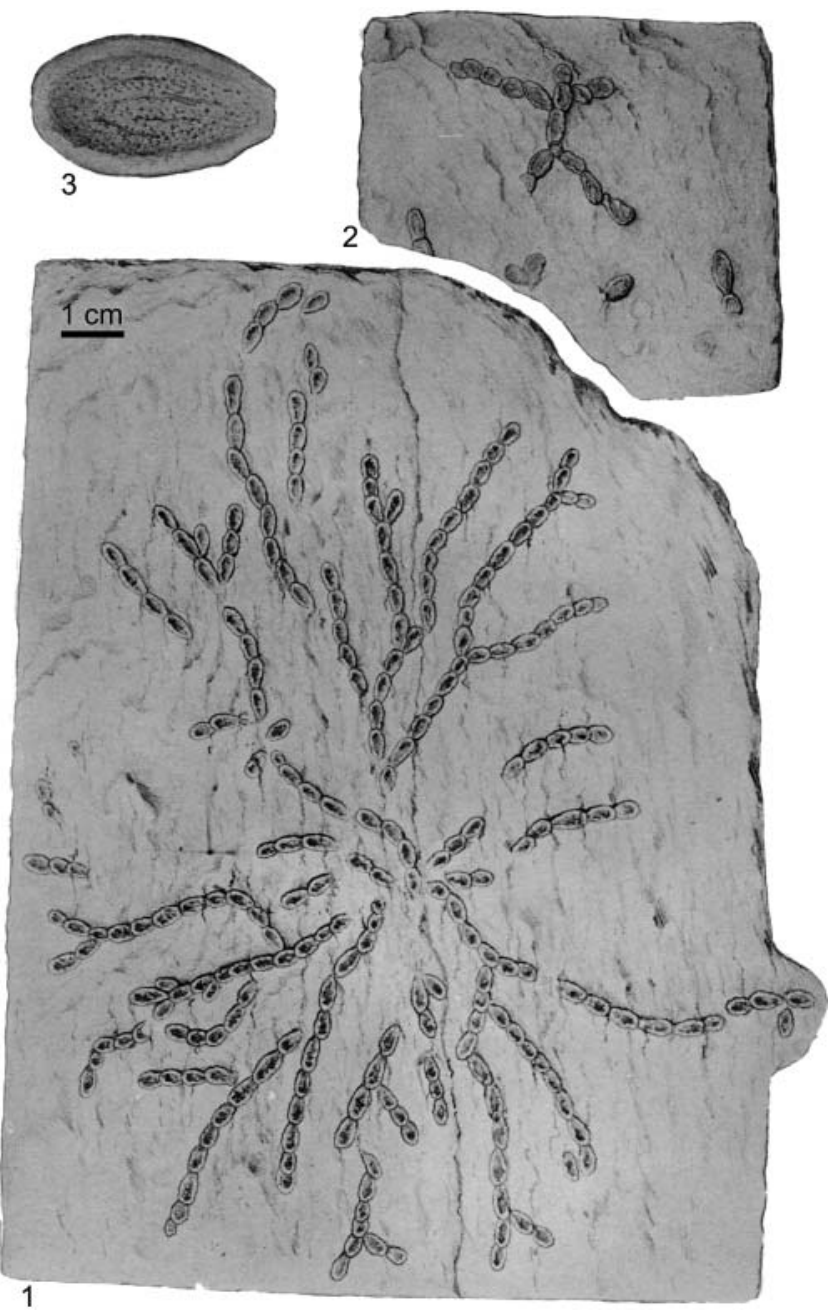

Fig. 1. Holotype of Arthrodendron diffusum, from Ulrich (1904): (1) 'a nearly complete specimen showing the mode of growth and the beaded or jointed character of the branches'; (2) 'several fragments on another piece of shale'; (3) 'one of the flattened elliptical joints of the preceding specimen $(\times 6.3)$ showing surface markings'

As pointed out by Reed (1952) this is undoubtedly the earliest valid use of the genus name Arthrodendron, and the name must be applied only with reference to Ulrich's Alaskan fossil. The calamite wood specimens from the Carboniferous were consequently renamed 'Arthroxylon' by Reed (1952). Nevertheless, the name Arthrodendron still persists in the popular literature in its original sense.

The homonymy of the name Arthrodendron Seward with Arthrodendron Ulrich was also pointed out by Dayal (1964). Unaware that Seward's Arthrodendron was, in fact, a nomen nudum, Dayal regarded Ulrich's form to be the junior homonym and renamed it Palaeoarthrodendron, a rather unfortunate choice of a name because Ulrich's genus was described from much younger strata. Because Ulrich's description of Arthrodendron is valid, the replacement name Palaeoarthrodendron must be rejected as a superfluous name under the rules of the ICZN (1999). Consequently, Arthrodendron Ulrich, 1904 is available in the sense of ICZN rules. Because the first valid use of the genus name Arthrodendron Ulrich is from the twentieth century and the name was used subsequently by Andrews (1955, 1970) and by Seilacher (1959), it is too young to be regarded as nomen oblitum under Paragraph 23.9.1 of the ICZN (1999).

Fortunately, many of the palaeontological specimens collected during the Harriman Alaskan Expedition have found their way to the Smithsonian Institution, where they are preserved in the collections of the Department of Paleobiology, including the specimens illustrated by Ulrich (1904; pl. 14, figs 1-3) (Fig. 1, Pl. 1). Without doubt, these specimens are not plants, but are large, agglutinated foraminifera, with a mineralized wall.

\section{Nineteenth century descriptions \\ Arthrodendron or Arthrodendron-like fossils have been reported in the macrofossil literature as either algae, trace fossils, or as body fossils of uncertain affinity. There are several examples of presumed Arthrodendron in the nineteenth century literature, variously described as species of Corallinites Unger, 1841, Hormosira Endlicher, 1836 or Halimeda Lamouroux, 1812. The earliest report is that of Unger (1841), who described the species Corallinites halimeda from the 'Jurassic' of Austria. This speci- men (Fig. 2a) shows strong similarity to Arthrodendron diffusum Ulrich. Massalongo (1856) described four additional species of Corallinites from the Tertiary marly limestones of the Vicento Province of Italy; Heer (1877) described the species Hormosira moniliformis from flysch sediments of Freiberg Canton, Switzerland; and Fuchs (1894) described the species Halimeda saportae from the Eocene Greifenstein Sandstone of Kritzendorf, Austria (Fig. 2b). All of these reports require further investigation to establish the possibility of synonymy with the type species of Arthrodendron. However, in each case the generic names applied were for green algae (Corallinites, Hormosira, Halimeda). Some of the species names described under these genera may be regarded as valid.}

\section{The genus Halysium Świdziński, 1934}

A potential subjective junior synonym of Arthrodendron is the genus Halysium Świdziński, 1934 (Fig. 2c) [non Halysium Corda, 1837; type species $H$. atrum Corda, 1837] described from the Late Cretaceous Inoceramian Beds at Przegonina near Gorlice, Carpathian flysch in Poland. This genus was included under 'Body Fossils' in the Treatise of Invertebrate Paleontology, Part W, by Häntzschel (1975), who listed Arthrodendron Ulrich as a junior synonym on the grounds of its supposedly being nomen nudem. However, now that status of the type specimens of Arthrodendron housed in the collections of the Smithsonian Institution has been clarified, this can no longer be the case. Halysium was described in the Treatise... (p. W151) as follows: 'Ovate capsules, commonly flattened, smooth or minutely granulated, consistency differing from matrix; some specimens with carbonaceous lining; capsules forming branching rows [?Alga]'.

The only described species, Halysium problematicum Świdziński, 1934 displays chambers that vary in size and are elongated, as in A. carpathica Neagu, 1964. However, the individual figured by Seilacher (1962) as H. problematicum (and reproduced in the Treatise...) displays uniformly oval chambers 

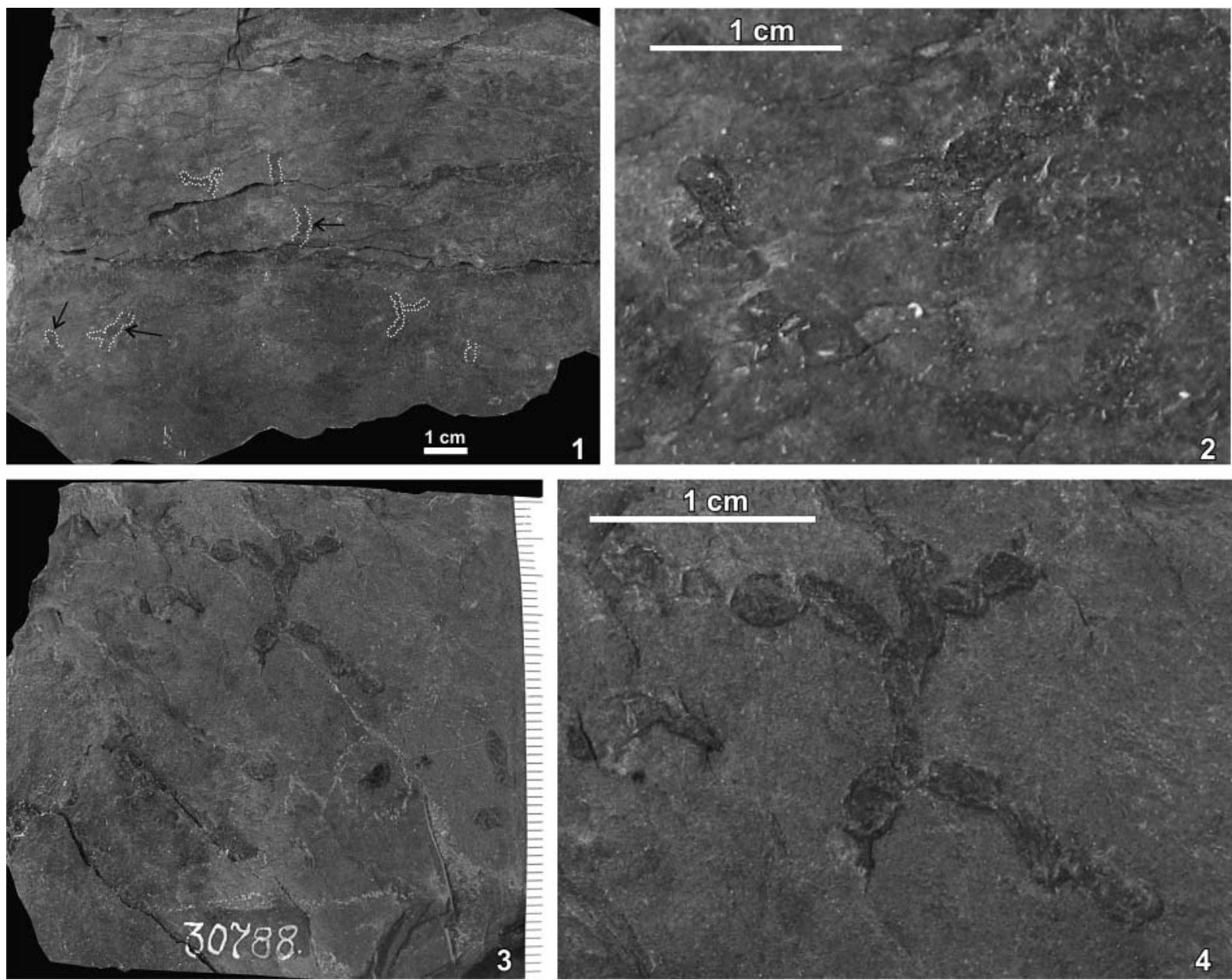

Explanation of Plate 1.

Type specimens of Arthrodendron diffusum Ulrich, 1904, from the Kodiak Formation of Pogibshi Island, Alaska, from the collections of the Department of Paleobiology, Smithsonian Institution. fig. 1. Lectotype (USNM 30787). Arrows point to most distinct chambers (outlined by dotted line). fig. 2. Detail of figure 1. fig. 3. Paralectotype (USNM 30788). fig. 4. Detail of figure 3. Photos by Bill DiMichele. Ruler for scale (in cm).

and more frequent branching than $A$. moniliformis, branching after only $2-5$ chambers. The whereabouts of Świdziński's specimen is unknown.

The name Halysium Świdziński is a junior homonym of the fungal genus Halysium Corda, 1837 (Index Fungorum, 2004) and, as a result, it is unavailable. To the authors' knowledge there is no replacement name for Halysium Swidziński. If it were a valid name, Halysium Świdziński would be placed into the synonymy of Arthrodendron Ulrich, based on descriptions and the similarity of the published illustrations. Additionally, the genus Halysium Świdziński was reported by Kern (1977) from the Upper Cretaceous Sieveringer Schichten of the Wienerwald flysch in Austria.

\section{Aschemonella carpathica Neagu, 1964}

Neagu (1964) described large-sized agglutinated foraminifera Aschemonella carpathica, A. moniliformis and Dendrophrya dichotomicus from the upper part of the Cretaceous Valea Mare Beds in the Teleajen Nappe of the Eastern Carpathians. The type specimens were found in reddish sediments of late Campanian age that are overlain by lower Maastrichtian grey marls in the Ulves Valley, near the Valea Mare, Romania (Neagu, 1968, 1970). The type description of Aschemonella carpathica Neagu, 1964 is as follows:

"Test free, moniliform, with an articulate aspect, dichotomically branched, consisting of numerous chambers with an oval-truncated-glandular contour. Parts connected with both the precedent and subsequent chamber nearly identical. Dimensions of chambers gradually but irregularly increasing. Test wall formed of quartz grains, mica flakes, sponge spicules, etc., of varying size, bound by an abundant siliceous cement. Wall thickness ca. $0.12 \mathrm{~mm}$. Chambers filled with a dark greenish argillaceous material. Apertures circular, situated on small necks either at the end of terminal chambers or on the sides of the chambers. The size of the specimens varies between 2-7 cm, thickness 1-3 mm."

The holotype specimen (Fig. 3) possesses chambers of varying length. Chambers on the central 'stem' are elongated, but chambers on lateral branches are smaller and more oval. Additional paratypes from the collection of the Laboratory of Palaeontology, University of Bucharest, are illustrated in 

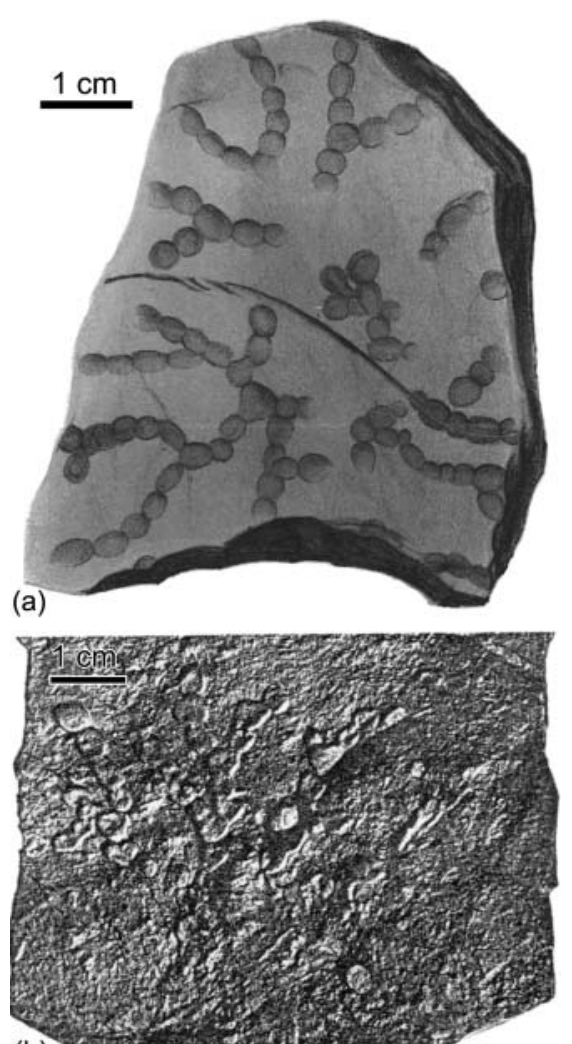

(b)

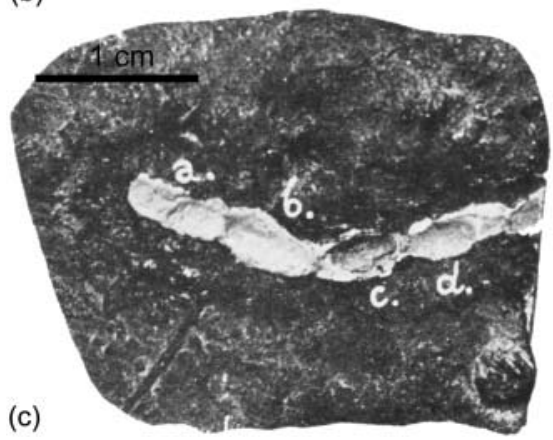

Fig. 2. Some synonyms of Arthrodendron: (a) type figure of Corallinites halimeda Unger, 1841, from 'Jurassic' limestone of Austria, from Unger (1841, pl. 39, fig. 7); (b) type specimen of Halimeda saportae Fuchs, 1894, from the Eocene Greifenstein sandstone of Austria, from Fuchs (1894, fig. 1); (c) holotype of Halysium problematicum Świdziński, 1934, from the Upper Cretaceous Inoceramian Beds at Przegonina, near Gorlice, Poland, from Świdziński (1934, fig. 2). The scale bars are approximate.

Plate 2. One of the specimens illustrated by Neagu (1964, pl. 26, fig. 5) was supplied by Stanisław Geroch. This specimen was collected from the Upper Cretaceous Inoceramian Beds of the Magura Nappe at Grybów, Poland. The Grybów locality is described in greater detail by Ślączka \& Kaminski (1998).

The genus Aschemocella Vialov, 1966 and the family Aschemocellidae Vialov, 1966

In the mid-1960s a series of papers was written by Soviet micropalaeontologists on the supposed Silicinifera, a group of foraminifera that were purported to have primary siliceous tests. A number of new genera were proposed by researchers such as

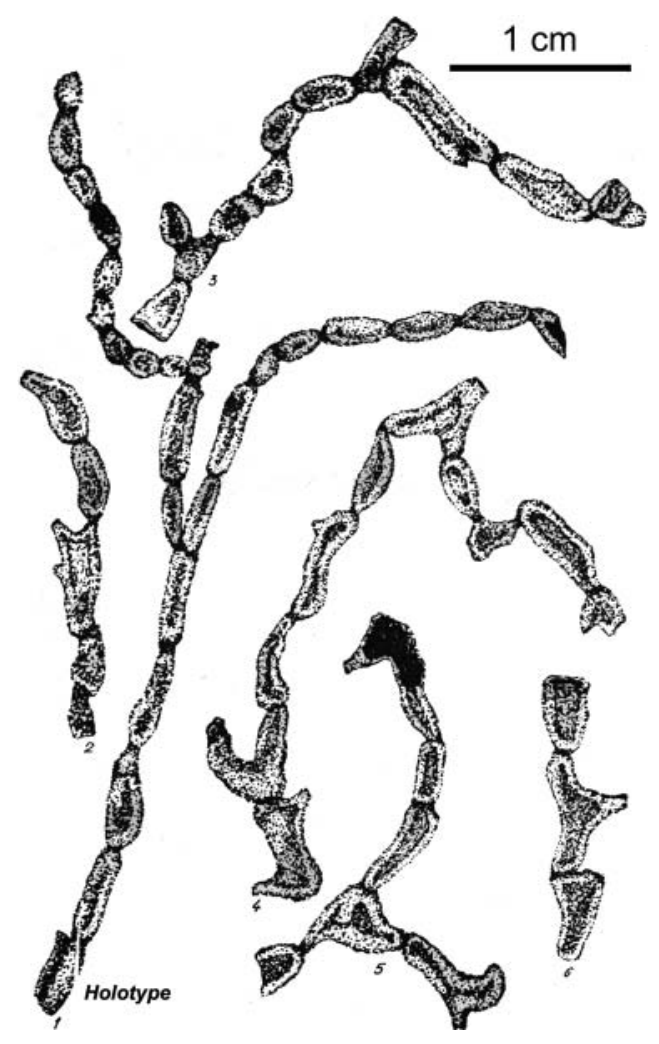

Fig. 3. Type specimens of Aschemonella carpathica Neagu, 1964, from the Valea Mare Beds, Braşov County, Romanian Carpathians, scale $=1 \mathrm{~cm}$ (from Neagu, 1964).

E. V. Mjatliuk (1966) and O. S. Vialov (1966) to separate the supposed 'siliceous' genera from their agglutinated homeomorphs. Unfortunately, for these authors, silicification of agglutinated foraminiferal tests turned out to be a purely diagenetic feature. As a result, whether or not an agglutinated test is silicified has no taxonomic significance, and most of the alleged 'siliceous' genera have been regarded subsequently as junior subjective synonyms.

One exception was the genus Aschemocella Vialov, 1966 (type species Aschemonella carpathica Neagu, 1964), which was considered by Loeblich \& Tappan (1987) to be a valid name for fossil foraminifera formerly placed in the genus Aschemonella. Moreover, Vialov (1966) established the family Aschemocellidae for his new genus Aschemocella. The type species of Aschemonella (A. scabra Brady, 1879) was discovered by Gooday \& Nott (1982) to synthesize barite crystals identical to those found in xenophyophoreans, and was transferred from the Foraminifera into the Xenophyophorea. A generic name was therefore required for the fossil foraminifera described as Aschemonella by Neagu (1964) from the Carpathian flysch. Vialov's genus Aschemocella served this purpose (see discussion by Berggren \& Kaminski, 1990). Since 1990, the genus name Aschemocella has been applied consistently to large, mostly fragmentary chambers of multilocular foraminifera recovered from deep-water turbidites (Kaminski \& Gradstein, 2005). However, the separation between the Xenophyophorea and the Foraminifera was brought into question by the discovery of Pawłowski et al. 

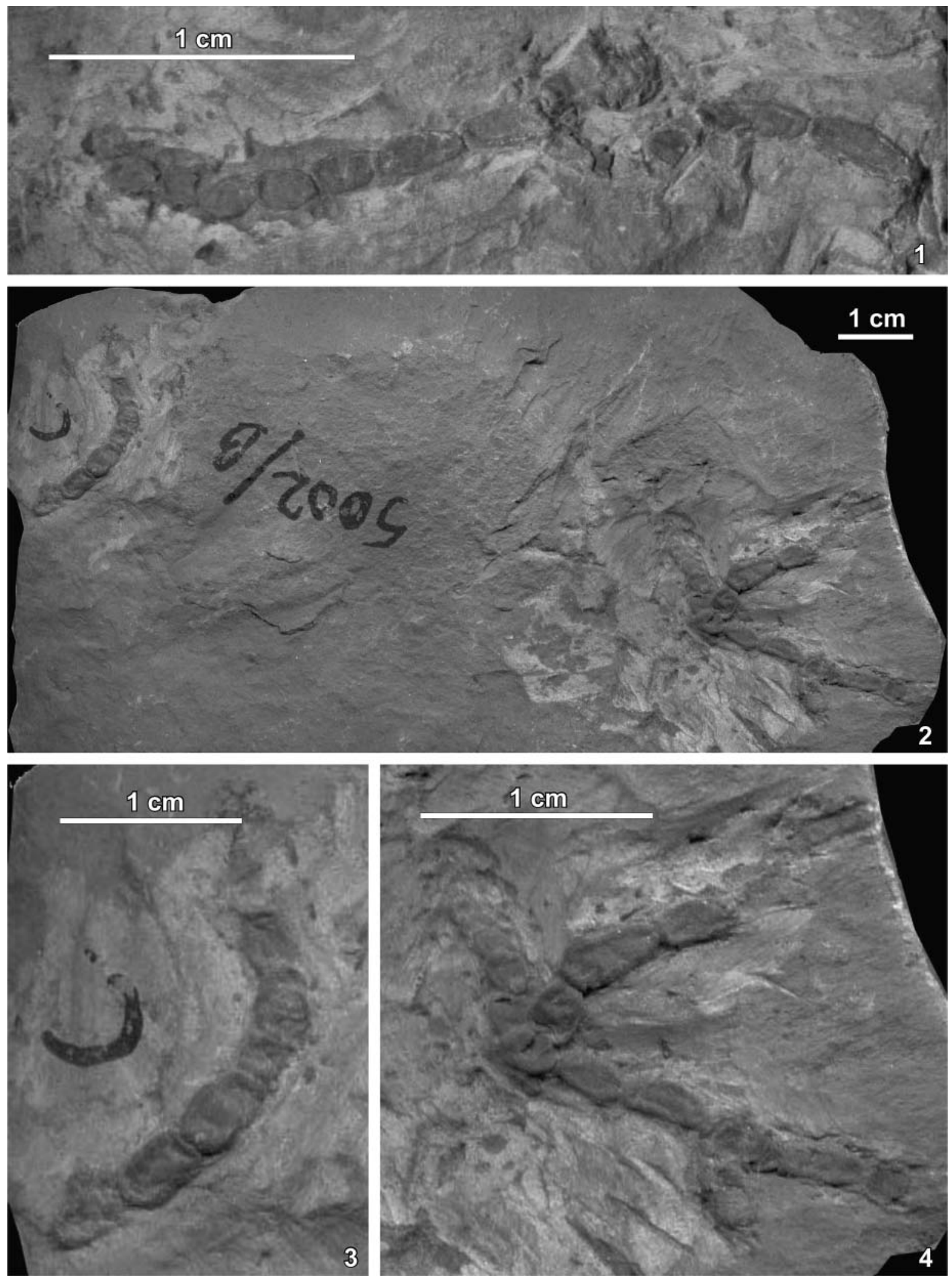

Explanation of Plate 2.

Paratype specimens of Aschemonella carpathica Neagu, 1964, from the upper Campanian Valea Mare Beds, Brașov County, Eastern Carpathians, Romania, from the collections of the Laboratory of Paleontology, University of Bucharest, photographs by Cristian Foceanu. fig. 1. Specimen LPB 5002/F. fig. 2. Specimen LPB 5002/B. figs 3-4. Details of figure 2. 
(2003) that the xenophyophorean Syringammina corbicula is a foraminifer based on ribosomal DNA analysis. More molecular studies are needed to determine whether the taxonomic separation between Xenophyophorea and the Foraminifera should be maintained.

\section{SYSTEMATIC PALAEONTOLOGY}

Family Aschemocellidae Vialov, 1966

1966 Aschemocellidae Vialov: 31. Subsequent designation: 1987 Loeblich \& Tappan: 55; 2004 Kaminski: 246; 2004 Mikhalevich: 339.

1974 Aschemocellinae Loeblich \& Tappan: 43, nom. transl. ex family Aschemocellidae.

Type genus. Arthrodendron Ulrich, 1904.

Description. Test free, dichotomously branched, of ovoid to tubular or irregular uniserial chambers; wall imperforate, agglutinated, firmly cemented; apertures at ends of necks.

Remarks. The family name Achemocellidae is here maintained as valid according to recommendations of Article 40.1 of the ICZN. Irrespective of the validity of the generic name, the family name Aschemocellidae Vialov is conserved.

In the most recently published suprageneric classifications (Kaminski, 2004; Mikhalevich, 2004) the Aschemocellidae was placed within the Superfamily Hormosinacea (or Hormosinoidea). Because of its large dimensions and catenate branching morphology, Arthrodendron bears superficial resemblance to the komokiacean genus Catena Schroeder, Medioli \& Scott, 1989. This brings into question the systematic affiliation of the Family Aschemocellidae. The Superfamily Komokiacea encompass typically large, branching forms that are either unchambered or pseudochambered, and differ from other foraminifera in accumulating stercomata (faecal pellets) inside their tests. Because of their weakly cemented wall, the komokiaceans are not known to leave a fossil record. If it turned out that Arthrodendron accumulated stercomata, based on external morphology the Family Aschemocellidae would fit better within the Komokiacea. Until this matter is resolved, the Aschemocellidae are tentatively retained within the Hormosinoidea.

\section{Genus Arthrodendron Ulrich, 1904}

1904 Arthrodendron Ulrich: 138, pl. 14, figs 1-3 [type species: Arthrodendron diffusum Ulrich, 1904].

1934 Halysium Świdziński: 146 [type species: Halysium problematicum Świdziński, 1934; non Halysium Corda, 1837].

1964 Palaeoarthrodendron Dayal: 727 [nom. subst. pro Arthrodendron Ulrich, 1904].

1966 Aschemocella Vialov: 31 [type species: Aschemonella carpathica Neagu, 1964].

Type species. Arthrodendron diffusum Ulrich, 1904, p. 138, by original designation. [Subjective junior synonym: Aschemonella carpathica Neagu, 1964, p. 582].

Type specimens. The two specimens illustrated by Ulrich (1904, pl. 14, figs 1, 2) are housed in the Department of Paleobiology,
National Museum of Natural History, Smithsonian Institution, Washington D.C. The specimen illustrated by Ulrich in his fig. 1 (USNM 30787) is designated here as the lectotype (Pl. 1, figs 1-2). The paralectotype (Ulrich's fig. 2) is registered as USNM 30788 (Pl. 1, figs 3-4).

Type locality. The holotype of A. diffusum was collected by G. K. Gilbert during the 1899 Harriman Alaskan Expedition from the 'Yakutat Formation' (now the Kodiak Formation within the Yakutat Group) on Pogibshi Island separated by a narrow strait from the Kodiak Island opposite the town of 'Kadiak' [now Kodiak], Alaska. The accompanying trace fossil assemblage found at the locality included Chondrites and graphoglyptids, indicating a deep-sea environment. Sedimentological (Nielsen \& Moore, 1979) and ichnological studies (McCann \& Pickerill, 1988) indicate that the Kodiak Formation was deposited in a distal deep-sea fan turbidite setting.

Type level. The Kodiak Formation is now regarded to be of Late Cretaceous (Early Maastrichtian) age on the basis of inoceramid bivalves (Jones \& Clark, 1973).

Diagnosis. Branched chains of large, often irregular chambers with a simple, imperforate, agglutinated wall.

Description. Test free, with large (commonly $1-3 \mathrm{~mm}$ wide) irregularly ovoid, flask-shaped, or tubular chambers in a linear or dichotomously branching series, increasing very slowly in size. Chambers are compressed with a raised outer rim and may have irregular shape at the point of branching. Wall imperforate, simple, of agglutinated quartz, mica, and sponge spicules in abundant cement, probably with an inner organic lining. May have more than one rounded aperture, which may be produced on a neck, terminal, or may be at the side of the chamber, probably just before a new branch arises.

Occurrence. Upper Cretaceous (Campanian-Maastrichtian) in Alaska, Austria, Italy, Poland, Romania, Slovakia, Switzerland, Ukraine; Palaeogene in Austria, Italy, Poland, Switzerland, Trinidad and the North Sea.

Remarks. The similarity between the type species A. diffusum Ulrich, 1904 and the species Aschemonella carpathica Neagu, 1964 is striking. Both species are reported from rocks of similar age and palaeoenvironment. Ulrich reported the thickened rims around the individual chambers of $A$. diffusum, a feature that is also typical of the type specimens of $A$. carpathica.

At least four valid species of Arthrodendron have been reported from Late Cretaceous to Palaeogene aged deep-sea sediments under various generic names. In addition to the type species $A$. diffusum (=A carpathica Neagu, 1964), the species $A$. moniliformis (=Aschemonella moniliformis Neagu, 1964), $A$. grandis (=Reophax grandis Grzybowski, 1898) and $A$. subnodosiformis (=Hyperammina subnodosiformis Grzybowski, 1898) are commonly reported from deep-sea turbiditic deposits, mostly in the Carpathians. The latter two species were transferred to the genus Aschemocella by Kaminski \& Geroch (1993). However, the validity of the nineteenth century species originally described as fossil algae needs to be evaluated. It is possible that some of 
the species described by Unger (1847), Heer (1877) and by Fuchs (1894) may be senior synonyms of some of the species names in current usage.

The modern komokiacean genus Catena Schroeder, Medioli \& Scott, 1989 is externally very similar to Arthrodendron, and the question of their synonymy requires further investigation. The type species, Catena piriformis Schroeder, Medioli \& Scott, 1989 is a branching chain of elongated or pyriform chambers that may possess an additional aperture produced on a neck, as in Arthrodendron. Because of the presence of internal stercomata, Schroeder et al. (1989) placed their new genus in the Family Baculellidae Tendal \& Hessler, 1977 within the Superfamily Komokiacea. Whether or not Catena is a junior synonym of Arthrodendron remains an open question.

\section{CONCLUSIONS}

Larger agglutinated foraminifera commonly occur in Upper Cretaceous and Palaeogene flysch deposits world-wide. Some of these specimens have been historically referred to numerous genera of marine plants, body fossils of unknown affinity, or trace fossils. The valid generic name for such fossils is Arthrodendron Ulrich, 1904 (with the genera Halysium Świdziński, 1934, Palaeoarthrodendron Dayal, 1964 and Aschemocella Vialov, 1966 included as junior synonyms), which is transferred to the Foraminifera. The type species of the genus Aschemocella (Aschemonella carpathica Neagu, 1964) is here regarded to be a subjective junior synonym of Arthrodendron diffusum Ulrich, 1904. At least three additional species known from the AlpineCarpathian literature also belong in Arthrodendron Ulrich: $A$. moniliformis (Neagu, 1964), A. grandis (Grzybowski, 1898) and A. subnodosiformis (Grzybowski, 1898). The validity of the nineteenth century species originally described as fossil algae needs to be evaluated, as it is possible that some of the species described by Unger (1841), Heer (1877) and by Fuchs (1894) may be senior synonyms of some of the foraminiferal species names in current usage.

\section{ACKNOWLEDGEMENTS}

The authors thank Bill DiMichele, curator of fossil plants at the Department of Paleobiology, Smithsonian Institution, for checking the status of the type specimens of Arthrodendron and for making photographs. Cristian Foceanu (Bucharest) is also thanked for making new images of Aschemonella carpathica. Andy Gooday and John Gregory provided helpful reviews of the manuscript. The revision of agglutinated foraminiferal genera is supported by a consortium of oil companies (BP, Saudi Aramco, Shell, Total, PDVSA, Petronas, RPS Energy, Fugro Robertson). Additional support (to AU) was given by the Jagiellonian University. This is contribution no. 77 of the Deep-Water Agglutinated Foraminiferal Project.

\section{Manuscript received 20 March 2007 Manuscript accepted 6 February 2008}

\section{REFERENCES}

Andrews, H.N. 1955. Index of generic names of fossil plants, 1820-1950. Geological Survey Bulletin, 1013: 1-262.

Andrews, H.N. 1970. Index of generic names of fossil plants, 1820-1965. Geological Survey Bulletin, 1300: 1-354.
Berggren, W.A. \& Kaminski, M.A. 1990. Abyssal Agglutinates: Back to Basics. In: Hemleben, C., Kaminski, M.A., Kuhnt, W. \& Scott, D.B. (Eds), Paleoecology, Biostratigraphy, Paleoceanography and Taxonomy of Agglutinated Foraminifera. NATO ASI Series, C-327. Kluwer Academic Publishers, Dordrecht, 53-76.

Brady, H.B. 1879. Notes on some of the reticularian Rhizopoda of the 'CHALLENGER' Expedition; Part I. On new or little known Arenaceous types. Quarterly Journal of Microscopical Sciences, 19: 20-67.

Corda, A.C.I. 1837. Icones Fungorum hucusque Cognitorum, 1. Apud J.G. Calve, Prague, $32 \mathrm{pp}$.

Dayal, R. 1964. Palaeoarthrodendron, a revised name for Arthrodendron Ulrich. Current Science, 23: 716-717.

Endlicher, S. 1836-1840. Genera Plantarum Secundum Ordines. F. Beck, Vienna, 1483pp.

Fuchs, T. 1894. Über eine fossile Halimeda aus dem eocänen Sandstein von Greifenstein. Sitzungsberichte der Akademie der Wissenschaften, Mathematisch-Naturwissenschaftliche Klasse, 103: 200-204.

Geroch, S. 1960. Microfaunal assemblages from the Cretaceous and Paleogene Silesian Unit in the Beskid Ślęski Mts (western Carpathians). Biuletyn Instytutu Geologicznego (Warszawa), 153: $7-138$.

Gooday, A.J. \& Nott, J.A. 1982. Intracellular barite crystals in two xenophyophores, Aschemonella ramuliformis and Galatheammina sp. (Protozoa, Rhizopoda) with comments on the taxonomy of $A$. ramuliformis. Journal of the Marine Biological Association of the United Kingdom, 62: 595-605.

Grzybowski, J. 1898. Otwornice pokładów naftonośnych okolicy Krosna. Rozprawy Wydziatu Matematyczno-Przyrodniczego, Akademia Umiejętności w Krakowie, serya 2, 33: 257-305.

Heer, O. 1877. Flora Fossilis Helvetiae. Vorweltliche Flora der Schweiz. J. Wurster \& Co, Zurich, 182pp.

Häntzschel, W. 1975. Trace fossils and Problematica. In: Teichert, C. (Ed.), Treatise on Invertebrate Paleontology, Part W., Miscellanea, Supplement 1. Geological Society of America and University of Kansas Press, 1-269.

ICZN (International Commission for Zoological Nomenclature) 1999. International Code of Zoological Nomenclature, adopted by the International Union of Biological Sciences, 4th edn. International Trust for Zoological Nomenclature, London, 232pp.

Index Fungorum. 2004. Available on the World Wide Web at www.indexfungorum.org.

Jones, D.L. \& Clark, S.H.B. 1973. Upper Cretaceous (Maestrichtian) fossils from the Kenai-Chugach Mountains, Kodiak and Shumagin Islands, southern Alaska. Journal of Research of the U.S. Geological Survey, 1 (2): 125-136.

Kaminski, M.A. 2004. The Year 2000 classification of agglutinated foraminifera. In: Bubik, M. \& Kaminski, M.A. (Eds), Proceedings of the Sixth International Workshop on Agglutinated Foraminifera. Grzybowski Foundation Special Publication, 8: 237-255.

Kaminski, M.A. \& Geroch, S. 1993. A revision of foraminiferal species in the Grzybowski Collection. In: Kaminski, M.A., Geroch, S. \& Kaminski, D. (Eds), The Origins of Applied Micropaleontology: The School of Jozef Grzybowski. Grzybowski Foundation Special Publication, 1: 239-323.

Kaminski, M.A. \& Gradstein, F.M. 2005. Cenozoic cosmopolitan deepwater agglutinated foraminifera. Grzybowski Foundation Special Publication, 10: 547pp.

Kern, J.P. 1977. Lebensspuren und Paläeomilieu der Sieveringer Schichten (Oberkreide) des Wiener Waldes (Österreich). Mitteilungen der Gesellschaft der geologischen Bergbaustudien von Österreich, 24: $11-45$.

Lamouroux, J.V.F. 1812. Extrait d'un memoire sur la classification des polypieres coralligènes non entièrement pierreux. Nouveau Bulletin des Sciences, par la Société Philomatique de Paris, 3: 181-188.

Loeblich, A.R. \& Tappan, H. 1974. Recent advances in the classification of the Foraminifierda. In: Hedley, R.H. \& Adams, C.G. (Eds), Foraminifera, Vol. 1. Academic Press, London, 1-53.

Loeblich, A.R. \& Tappan, H. 1987. Foraminiferal Genera and their Classification. Van Nostrand Reinhold, New York, 970pp.

Massalongo, A. 1856. Studi Paleontologici. Antonelli, Verona, 53pp. 
McCann, T. \& Pickerill, R.K. 1988. Flysch trace fossils from the Cretaceous Kodiak Formation of Alaska. Journal of Paleontology, 62: 330-347.

Mikhalevich, V. 2004. On the heterogeneity of the former Textulariina (Foraminifera). In: Bubík, M. \& Kaminski, M.A. (Eds), Proceedings of the Sixth International Workshop on Agglutinated Foraminifera. Grzybowski Foundation Special Publication, 8: 317-349.

Mjatliuk, E.V. 1966. K voprosu o foraminiferakh c kremnevnym skeletom [On the question of foraminifera with a siliceous skeleton]. Voprosy Mikropaleontologii, 10: 255-269.

Neagu, T. 1964. Duże otwornice aglutynujęce z kampanu Karpat Rumuńskich (Large size agglutinated foraminifera from the Campanian of Rumanian Carpathians). Rocznik Polskiego Towarzystwa Geologicznego, 34: 579-588.

Neagu, T. 1968. Biostratigraphy of the Upper Cretaceous deposits in the southern Eastern Carpathians near Braşov. Micropaleontology, 14 (2): $225-241$.

Neagu, T. 1970. Micropaleontological and stratigraphical study of the Upper Cretaceous deposits between the upper valleys of the Buzău and Rîul Negru Rivers (Eastern Carpathians). Institut Geologique Memoires, Bucharest, 12: 1-204.

Nielsen, T.H. \& Moore, G.W. 1979. Reconnaissance study of Upper Cretaceous to Miocene stratigraphic units and sedimentary facies, Kodiak and adjacent islands, Alaska. Geological Survey Professional Paper, 1093: 1-34.

Pawłowski, J., Holzmann, M., Fahrini, J. \& Richardson, S.L. 2003. Small subunit ribosomal DNA suggests that the Xenophyophorean Syringammina corbicula is a foraminiferan. Journal of Eukaryotic Microbiology, 50: 483-487.

Plička, M. \& Thomka, V. 1990. Halimedaites carpathicus gen. n. sp. n., 'Body Fossil' from the Carpathian Flysch of Czechoslovakia. Západné Karpaty, Séria Paleontológia, 14: 125-132.

Reed, F.D. 1952. Arthroxylon, a redefined genus of Calamite. Annals of the Missouri Botanical Garden, 39: 173-187.

Schroeder, C.J., Medioli, F.S. \& Scott, D.B. 1989. Fragile abyssal foraminifera (including new Komokiacea) from the Nares Abyssal Plain. Micropaleontology, 35: 10-48.
Scott, D.H. 1900. Studies in Fossil Botany. Adam \& Charles Black, London, 533pp.

Seilacher, A. 1959. Zur ökologischen Characteristik von Flysch und Molasse. Eclogae Geologicae Helvetiae, 51: 1062-1078.

Seilacher, A. 1962. Paleontological studies on turbidite sedimentation and erosion. Journal of Geology, 70: 227-234.

Seward, A.C. 1898. Fossil Plants, 1. C.J. Clay \& Sons, London, 452pp.

Ślaczka, A. \& Kaminski, M.A. 1998. Guidebook to Excursions in the Polish Flysch Carpathians - Field excursions for Environmental Geoscientists. Grzybowski Foundation Special Publication, 6: 173pp.

Świdziński, H. 1934. Uwagi o budowie Karpat fliszowych (Remarks sur la structure des Karpates flyscheuses). Biuletyn Państwowego Instytutu Geologicznego, 8: 75-139.

Tendal, O.S. \& Hessler, R.R. 1977. An introduction to the biology and systematics of Komokiacea (Textulariina, Foraminiferida). Galathea Report, 14: 165-194.

Ulrich, E.C. 1904. Fossils and age of the Yakutat Formation. Description of the collections made chiefly near Kadiak, Alaska. In: Emerson, B.K., Palache, C., Dall, W.H., Ulrich, E.O. \& Knowlton, F.H. (Eds), Alaska, vol. 4, Geology and Paleontology. Doubleday, Page \& Co, New York, 125-146 [Reprinted in 1910 as the Smithsonian Institution Harriman Alaska Series, vol. 4].

Unger, F. 1841. Chloris Protogaea. Beiträge zur Flora der Vorwelt. Wilhelm Engelmann, Leipzig, 110pp.

Vialov, O.S. 1966. O krupnykh kremnistykh foraminiferakh Silicinifera iz Verkhnemelovogo flisha Karpat (Large siliceous foraminifer Silicinifera from the Upper Cretaceous flysch of the Carpathians). Paleontologichesky Shornik, L'vov, 3 (2): 27-36.

Williamson, W.C. 1871. On structure of the woody zone of an undescribed form of calamite. The Manchester Literary and Philosophical Society Memoir, 3rd Series, 4: 155-183. 